\title{
Accounting
}

\section{Determinants of Vietnam's export to EU market}

\author{
Thanh-Long Tran ${ }^{a^{*}}$ and Minh-Vuong Vo ${ }^{b}$
}

${ }^{a}$ University of Economics and Law (UEL), Ho Chi Minh City, Vietnam Vietnam National University Ho Chi Minh City (VNU-HCM), Ho Chi Minh City, Vietnam

${ }^{b}$ AEON Vietnam Co., Ltd., Ho Chi Minh City, Vietnam

CH R O I C L E A B S T R A C T

\section{Article history:}

Received April 12020

Received in revised format April

12020

Accepted April 272020

Available online

April 272020

Keywords:

EU market

Vietnam

Export

Gravity model
The paper uses the gravity model and panel data to examine the determinants of Vietnam's export to the EU market during the 2007-2017 period. The article uses the Hausman-Taylor estimator for the optimal combination of Fixed-Effects (FE) and Random-Effects (RE) methods. The estimation results indicate that the determinants of Vietnam's export to the EU market include: aggregate population $(+2,512)$; aggregate GDP per capita $(+1,256)$; Vietnam's index of infrastructure $(+0,824)$ and aggregate trade openness $(+0,377)$. Based on these results, the paper suggests policies to boost Vietnam's export to the EU.

\section{Introduction}

In the context of international economic integration, Vietnam is among countries with very high export growth. According to the data from UN Comtrade, Vietnam recorded very high export turnovers in the 2007-2017 period with 4.5 times increase in export volumes, from 48 billion USD in 2007 to 215 billion USD in 2017 (COMTRADE, 2017). The European Union (EU) is the largest economy in the world with a GDP of 18.82 trillion USD and a population of 512 million in 2017 and is also the second-largest import market of Vietnam. In 2017, Vietnam's export turnover to the EU market reached 38.31 billion USD, placing it second to only our export turnover to the US (41.5 billion USD) and above China (35 billion USD) (COMTRADE, 2017). A special characteristic in the two-way trade relationship between Vietnam and the EU is the high complementarity and low competitiveness, which favours Vietnam's exportation. However, Vietnam's export maintains a modest position in the EU. According to UN Comtrade's data, Vietnam's exports only accounted for $1.99 \%$ of the EU's import turnover in 2017 (COMTRADE, 2017). Therefore, the paper raises the following research question: Which are determinants of Vietnam's export to the EU market? In search of an answer to the question above, the paper uses the gravity model to evaluate the determinants of exports or trade flows of a country. In particular, relevant domestic studies include Tho (2013), Mai (2017) with a focus on Vietnam's exports, Duong (2016) on trade flows between Vietnam and the EU. Through prior studies from Vietnamese authors, there has not been any research that thoroughly examines the determinants of Vietnam's export to the EU market. Therefore, it is necessary to estimate the determinants of Vietnam-EU export market growth. The paper is structured as follows. Section 2 includes theoretical framework and proposed research model. Section 3 is about data and methods. Section 4 presents empirical results. Section 5 concludes.

* Corresponding author.

E-mail address: longtt@uel.edu.vn (T.-L. Tran) 


\section{Theoretical framework}

Export is the exchange of goods and services from one country to another through market relations to make use of the country's advantages and thus allow the country to benefit from them. Export activities can take various forms, mainly in the following five: direct export, indirect export, re-export, on-site export and export processing. In terms of economic development of a country, export plays four main roles: First, export serves as the primary capital source for import to augment the industrialization process of the country; Secondly, export contributes to economic restructuring and endorses production; Thirdly, export improves the employment situation as well as living circumstances; Lastly, export is fundamental to expand and promote foreign economic relations. The gravity model of international trade is used by many economic researchers worldwide to analyse trade activities between two or more countries. The model's application was first reported by (Tinbergen, 1962) and (Pöyhönen, 1963) in the following form:

$$
X_{i j}=\varphi\left(\frac{Y_{i} \times Y_{j}}{D_{i j}}\right)
$$

where $\varphi$ is the constant;

$X_{i j}$ is the value of trade flow from country $\mathrm{i}$ to country $\mathrm{j} ; Y_{i}$ and $Y_{j}$ are respectively the gross domestic product (GDP) of country $\mathrm{i}$ and $\mathrm{j}$ and finally, $D_{i j}$ is the geographical distance between country $i$ and $j$. The value of export flow from country $i$ to country $\mathrm{j}$ is positively correlated with the GDP of each country and negatively correlated with the geographical distance between the two countries. From the initial research model, researchers have also included other factors into the model, such as per capita income, tariffs (Linnemann, 1966), border effects (Anderson, 1979), commodity prices, real exchange rates (Bergstrand, 1985), expenditure capabilities, taste preferences (Bergstrand, 1989), while other researchers helped to improve the model, such as Helpman and Krugman (1985), Anderson (1979), and Song (2011). Based on all studies mentioned above, the current generalized gravity model includes three main groups of factors impacting export or trade flows, namely supply-side factors (regarding exporting country $i$ ) demand-side factors (regarding importing country $j$ ), as well as facilitating and obstructing factors. The generalized gravity model has the following linear form:

$$
\ln T_{i j}=\beta_{0}+\beta_{1} \ln X_{1}+\cdots+\beta_{n} \ln X_{n}+\alpha_{1} D_{1}+\cdots+\alpha_{m} D_{m}+u_{i j}
$$

where, $k=1,2,3, \ldots, n$ is the value of the independent variable $X_{k}, n$ is the number of independent quantitative variables; $l=$ $1,2,3, \ldots, m$ is the value of dummy variable $D_{l}$, which takes the value of 1 under certain circumstances and equals 0 otherwise; $\mathrm{m}$ is the number of dummy variables. This paper uses the generalized gravity model (2) to propose a research model for examining the determinants of Vietnam's export to the EU market. The focal point of the research model is that the author uses the variable combination method to better identify the impact of such factors on export and uses delayed variables to eliminate the impact of the dependent variable (export turnover) on independent variables (including GDP) (Nguyen, 2010; Tesfaye, 2014; Duong, 2016). The model can be expressed in the natural logarithmic form as follows:

$$
\begin{aligned}
& \ln \left(1+E X_{i j t}\right)=\beta_{0}+\beta_{1} \ln \left(P G D P_{i(t-1)} * P G D P_{j(t-1)}\right)+\beta_{2} \ln \left(P O P_{i t} * P O P_{j t}\right)+\beta_{3} \ln \left(D I S T_{i j}\right)+ \\
& \beta_{4} \ln \left(R E R_{i j t}\right)+\beta_{5} \ln \left(I N F R A S_{i t}\right)+\beta_{6} \ln \left(T E C H_{i t}\right)+\beta_{7} \ln \left(O P E N_{i(t-1)} * O P E N_{j(t-1)}\right)+u_{i t},
\end{aligned}
$$

where:

$i$ : exporting country (Vietnam), $(j=1,2, \ldots 28)$ : importing countries (28 EU countries), $t=2007,2008, \ldots, 2017$.

$\ln \left(1+E X_{i j t}\right):$ Logarithm of Vietnam's export turnover to importing country $\mathrm{j}$ in year $\mathrm{t}$. As there was no record of Vietnam's export turnover to some importing countries $\mathrm{j}$ (which did not indicate the lack of export activities), the author uses $\ln \left(1+E X_{i j t}\right)$ for accuracy.

$P G D P_{i(t-1)} * P G D P_{j(t-1)}$ : The combined variable of real GDP per capita of Vietnam and of importing country $\mathrm{j}$ in the year $(\mathrm{t}-1)$.

$P O P_{i t} * P O P_{j t}$ : The combined variables of the population of Vietnam and of importing country $j$ in year $t$.

$D I S T_{i j}$ : The geographical distance between Hanoi and the capital of importing country $j$.

$R E R_{i j t}$ : The real exchange rate between VND and the currency of importing country $j$ in year $t$.

INFRAS $i t$ : Vietnam's index of infrastructure in year $t$.

$T E C H_{i t}$ : Vietnam's technology readiness index in year $t$.

$O P E N_{i(t-1)} * O P E N_{j(t-1)}$ : The aggregate trade openness of Vietnam and importing country $j$ in the year $(\mathrm{t}-1)$.

$u_{i t}$ : Random error of the model

Expected sign: $\beta_{1}, \beta_{2}, \beta_{4}, \beta_{5}, \beta_{6}, \beta_{7}>0$ and $\beta_{3}<0$.

\section{Data and methods}

The article uses the panel data of Vietnam and 28 EU countries from the 2007-2017 period. The author applies the HausmanTaylor estimator (Hausman \& Taylor, 1981) for the optimal combination of Fixed-effects (FE) and Random-effects (RE) for panel data. This paper uses the statistical software Stata 13.0. The author uses panel data of Vietnam and 28 EU countries, 
including Belgium, Germany, The Netherlands, Luxembourg, France, Italy, England, Denmark, Ireland, Greece, Portugal, Spain, Austria, Finland, Sweden, Poland, Estonia, Hungary, Latvia, The Czech Republic, The Republic of Cyprus, Slovakia, Slovenia, Bulgaria, Romania, and Croatia (by accession). The data were collected over the 2007-2017 period, with the data source as presented in Table 1. The paper uses the Hausman-Taylor estimator to combine the strength of two models FEM and REM, which are broadly used in panel data. The author selects the suitable model among OLS, FEM, and REM by BreuschPagan Lagrange Multiplier Test (LM) and Hausman Test, and thereafter runs appropriate tests to identify and revise limitations.

Table 1

The source of data

\begin{tabular}{|c|c|c|c|}
\hline Research data & Source & Research data & Source \\
\hline Export turnover & UN Comtrade & Real exchange rate & IMF \\
\hline GDP per capita & World Bank & Index of Infrastructure & WEF \\
\hline Population & World Bank & Technology Readiness Index & WEF \\
\hline Geographical distance & Timeanddate & Trade openness & UN Comtrade \\
\hline
\end{tabular}

\section{Empirical results}

As aforementioned, the author first applies pooled OLS and RE estimators and conducts tests on estimation results. Next, FEM is employed and the Hausman Test is operated to decide the best method between REM and FEM. As a result, FEM is selected. Consequently, through the Breusch-Pagan Lagrange Multiplier Test (LM), REM is proved to be the optimal method. Limitations of FEM are examined, where heteroscedasticity is detected (Table 2). Hence, the Hausman-Taylor estimator is employed to rectify the above limitation. The author uses the estimation results of the Hausman-Taylor estimator to discuss the study result. According to the Hausman-Taylor results (Table 3) of the model, the determinants of Vietnam's export turnover in the EU market have the following statistical meanings: aggregate GDP per capita $(+1.2561)$, the aggregate population $(+2.5124)$, Vietnam's index of infrastructure $(+0.8243)$ and aggregate trade openness $(+0.3773)$. First, at $1 \%$ significance level, the aggregate population is positively correlated with Vietnam's export turnover to the EU market. If the coefficient increases by $1 \%$, export turnover increases by $2.5124 \%$. This result is consistent with the research hypothesis and the studies by Trần Nhuận Kiên and Ngô Thị Mỹ (2015), and Do Thi Hoa Nha and Nguyen Thi Thanh Ha (2019).

Table 2

The results of estimation

\begin{tabular}{|c|c|c|c|}
\hline Variables & Pooled OLS & REM & FEM \\
\hline Intercept & $-6.452429 * * *$ & $-7.023896^{* * *}$ & $-34.29212 * * *$ \\
\hline $\ln \left(P G D P_{i(t-1)} * P G D P_{j(t-1)}\right)$ & $1.062562 * * *$ & $1.10388 * * *$ & $0.901043 * *$ \\
\hline $\ln \left(P O P_{i t} * P O P_{j t}\right)$ & $1.198067^{* * *}$ & $1.175603 * * *$ & $5.512278^{* * *}$ \\
\hline $\ln \left(D I S T_{i j}\right)$ & -0.660973 & -0.396850 & - \\
\hline $\ln \left(R E R_{i j t}\right)$ & $0.204632 * * *$ & 0.081479 & -0.004301 \\
\hline $\ln \left(I N F R A S_{i t}\right)$ & 0.672381 & $1.08159 * *$ & 0.335297 \\
\hline $\ln \left(T E C H_{i t}\right)$ & -0.133621 & -0.273596 & -0.430944 \\
\hline $\ln \left(O P E N_{i(t-1)} * O P E N_{j(t-1)}\right)$ & $0.785364 * * *$ & $0.550127 * * *$ & $0.381453 * *$ \\
\hline R-squared & 0.8604 & 0.8528 & 0.7088 \\
\hline Breusch-Pagan Lagrange (LM) test $154.36(0.0000)$ Hausm & t $22.81(0.0009)$ & Wald test $14392.53(0.0000)$ & Number of Observations $=308$ \\
\hline
\end{tabular}

Secondly, at a $1 \%$ significance level, aggregate GDP per capita is positively correlated with Vietnam's export turnover to the EU market. If the coefficient increases by $1 \%$, export turnover increases by $1.2561 \%$. This result is consistent with the research hypothesis and the studies by Trần Nhuận Kiên and Ngô Thị Mỹ (2015), and Do Thi Hoa Nha and Nguyen Thi Thanh Ha (2019). Thirdly, at a 5\% significance level, aggregate trade openness is positively correlated with Vietnam's export turnover to the EU market. If the coefficient increases by $1 \%$, export turnover increases by $0.3773 \%$. This result is consistent with the research hypothesis and the study by Abidin and Sahlan (2013), Trần Nhuận Kiên and Ngô Thị Mỹ (2015), and Do Thi Hoa Nha and Nguyen Thi Thanh Ha (2019). Fourthly, at a 10\% significance level, Vietnam's index of infrastructure is positively correlated with Vietnam's export turnover to the EU market. If the coefficient increases by 1\%, export turnover increases by $0.8243 \%$. This result is consistent with the research hypothesis and the studies by Martínez-Zarzoso and Nowak-Lehmann (2003).

\section{Table 3}

Hausman-Taylor Estimation Results

\begin{tabular}{lcc}
\hline Variables & Coefficients & Variables \\
\hline Intercept & -1.841424 & \multicolumn{1}{c}{ Coefficients } \\
$\ln \left(P G D P_{i(t-1)} * P G D P_{j(t-1)}\right)$ & $1.256115^{* * *}\left(R E R_{i j t}\right)$ & -0.048853 \\
$\ln \left(P O P_{i t} * P O P_{j t}\right)$ & $2.512462 * * *$ & $\ln \left(I N F R A S_{i t}\right)$ \\
$\ln \left(D I S T_{i j}\right)$ & -6.807384 & $\ln \left(T E C H_{i t}\right)$ \\
\hline
\end{tabular}

Notes: ${ }^{* *},{ }^{* *},{ }^{*}$ respectively represent a significance level of $1 \%, 5 \%$ and $10 \%$. Source: Authors' estimation from Stata 13 


\section{Conclusion and implication}

Based on the above research results, this paper has proposed the following policy implications to boost Vietnam's export turnover to the EU market. First, aggregate GDP per capita should be taken into consideration. It is vital for Vietnam to maintain high growth rate to create stable conditions for the export growth to the EU market: persistently aiming to maintain macroeconomic stability, regulating inflation, preserving the economy's major balances, improving the business investment environment, endorsing economic growth; promoting institutional improvement, improving the appraisal of legal documents to ensure the uniformity and feasibility of the legal system; advocating economic restructuring in line with the innovation of growth model, enhancing growth quality, labour productivity and the competitiveness of the economy to make more substantial changes in every sector and industry, with regard to the implementation of the national strategy for the Industry 4.0. Regarding EU countries, export to markets with high GDP per capita should be promoted. Secondly, the aggregate population should be taken into consideration. Vietnam's Government should make use of abundant labour supply in both quantity and quality, focus on the specialization of the labour force and attract talents. For EU countries, exports to highly populated countries should be promoted. Thirdly, the infrastructure of Vietnam should be taken into consideration. The Government should take measures to modernize the economic infrastructure (including hard and soft infrastructure). Fourthly, the aggregate trade openness should be taken into consideration. The Government should endorse negotiations as well as bilateral and multilateral free trade agreements, strengthen trade promotion activities to boost Vietnam's exports to other markets and in turn attract investment in terms of capital, modern technology, and equipment from these countries. This study has estimated the impact level of determinants of Vietnam's export turnover to the EU market. However, the study is subject to the following limitations: the study has not quantitatively analysed specific key export products to the EU, nor has it utilized SWOT Analysis. Therefore, it is possible to do some research on Vietnam's key export products to the EU market in details by applying SWOT Analysis.

\section{References}

Abidin, I. S. Z., \& Sahlan, R. (2013). The determinants of exports between Malaysia and the OIC member countries: A gravity model approach. Procedia Economics and Finance, 5, 12-19.

Anderson, J. E. (1979). A theoretical foundation for the gravity equation. The American economic review, 69(1), $106-116$.

Bergstrand, J. H. (1985). The gravity equation in international trade: some microeconomic foundations and empirical evidence. The Review of Economics and statistics, 474-481.

Bergstrand, J. H. (1989). The generalized gravity equation, monopolistic competition, and the factor-proportions theory in international trade. The review of economics and statistics, 143-153.

COMTRADE. (2017). Retrieved from https://comtrade.un.org/data/

Do Thi Hoa Nha, \& Nguyen Thi Thanh Ha. (2019). Phân tích các yếu tố tác động đến xuất khẩu nông sản của Việt Nam sang thị trường EU. Tạp chi Khoa học và Công nghệ-Đại học Thái Nguyên, 196(3), 123-129.

Duong, N. B. (2016). Vietnam-EU free trade agreement: Impact and policy implications for Vietnam. SECO/WTI Academic Cooperation Project Working Paper Series, 7.

Hausman, J. A., \& Taylor, W. E. (1981). Panel data and unobservable individual effects. Econometrica: Journal of the Econometric Society, 1377-1398.

Helpman, E., \& Krugman, P. R. (1985). Market structure and foreign trade: Increasing returns, imperfect competition, and the international economy: MIT press.

Linnemann, H. (1966). An econometric study of international trade flows: North-Holland Pub. Co.

Mai, T. T. C. (2017). Estimating the impact of export costs on Vietnam ${ }^{\text {ee }}$ s export. Science \& Technology Development Journal-EconomicsLaw and Management, 1(Q5), 74-81.

Martínez-Zarzoso, I., \& Nowak-Lehmann, F. (2003). Augmented gravity model: An empirical application to Mercosur-European Union trade flows. Journal of applied economics, 6(2), 291-316.

Nguyen, B. X. (2010). The determinants of Vietnamese export flows: Static and dynamic panel gravity approaches. International Journal of Economics and Finance, 2(4), 122-129.

Pöyhönen, P. (1963). A tentative model for the volume of trade between countries. Weltwirtschaftliches Archiv, 93-100.

Song, E. Y. (2011). On Gravity, Specialization and Intra-industry Trade. Review of International Economics, 19(3), 494-508.

Tesfaye, E. (2014). Determinants of agricultural export in Sub-Saharan Africa: evidence from panel study. American Journal Of Trade And Policy, 1(2), 62-70.

Tho, N. H. (2013). Determinants of Vietnam's Exports: A Gravity Model Approach. School of Management and Economics, Assumption University, Bangkok, Thailand.

Tinbergen, J. (1962). Shaping the world economy; suggestions for an international economic policy.

Trần Nhuận Kiên, \& Ngô Thị Mỹ. (2015). Các nhân tố tác động đến kim ngạch xuất khẩu nông sản Việt Nam: Phân tích bằng mô hình trọng lực. Tạp chí Nhũng vấn đề Kinh tế \& Chính trị thế giới, 3(227), 47-52.

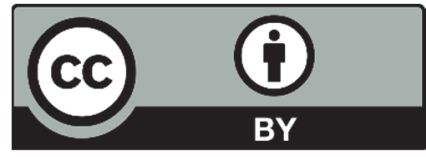

(C) 2020 by the authors; licensee Growing Science, Canada. This is an open access article distributed under the terms and conditions of the Creative Commons Attribution (CC-BY) license (http://creativecommons.org/licenses/by/4.0/). 